\begin{tabular}{|c|c|c|}
\hline $\begin{array}{l}\text { JURNAL } \\
\text { INOVASI } \\
\text { TEKNOLOGI }\end{array}$ & $\begin{array}{l}\text { Jurnal Inovasi Teknologi Pendidikan } \\
\text { Volume 4, No 1, April } 2017 \text { (50-64) }\end{array}$ & Ikatan Profesi Teknologi \\
\hline PENDIDIKAN & Online: http://journal.uny.ac.id/index.php/jitp & Pendidikan Indonesia \\
\hline
\end{tabular}

\title{
IMPLEMENTASI KURIKULUM 2013 DALAM PELAKSANAAN PEMBELAJARAN DI SMP
}

\author{
Mastur \\ Universitas Lambung Mangkurat \\ masturguru@gmail.com
}

\begin{abstract}
Abstrak
Penelitian ini bertujuan untuk mendeskripsikan: (a) perencanaan pembelajaran, (b) pelaksanaan pembelajaran, (c) pelaksanaan penilaian, dan (d) faktor penghambat dan pendukung pelaksanaan pembelajaran dalam rangka mengimplementasikan Kurikulum 2013 di SMP N 8 Yogyakarta. Penelitian ini menggunakan pendekatan deskriptif kualitatif. Subjek penelitian ini adalah personel yang berkaitan dengan implementasi Kurikulum 2013 dalam pelaksanaan pembelajaran di SMP N 8 Yogyakarta yang terdiri dari kepala sekolah, wakil kepala sekolah bagian kurikulum, guru, dan siswa. Pengumpulan data dilakukan melalui observasi partisipan, wawancara mendalam, dan dokumentasi. Keabsahan data dilakukan dengan cara ketekunan pengamatan, triangulasi data dan pemeriksaan data. Data penelitian ini dianalisis secara terus-menerus sejak awal pengumpulan data dan melelaui tiga tahap yaitu reduksi data, penyajian data, dan pengambilan kesimpulan. Hasil penelitian mengungkapkan: (1) perencanaan pembelajaran dilakukan dengan menerjemahkan ide dan konsep Kurikulum 2013 terlebih dahulu, kemudian disusun RPP yang dikembangkan secara rinci dari suatu materi pokok atau tema tertentu yang mengacu pada standar isi dan silabus; (2) pelaksanaan pembelajaran dilaksanakan dengan menggunakan pendekatan ilmiah (saintifik); (3) penilaian hasil belajar oleh guru dilakukan dengan menggunakan teknik tes, tertulis maupun lisan, juga teknik non-tes, pengamatan kinerja dan pengukuran sikap.
\end{abstract}

Kata kunci: implementasi, Kurikulum 2013, pelaksanaan pembelajaran

\section{THE IMPLEMENTATION OF CURRICULUM 2013 ON INSTRUCTIONAL ACTIVITIES IN JUNIOR HIGH SCHOOL}

\author{
Mastur \\ Universitas Lambung Mangkurat \\ masturguru@gmail.com
}

\begin{abstract}
This study aims to describe: (a) the lesson plan, (b) the instructional implementation, (c) the implementation of assessment, and (d) the factors obstructing and supporting the instruction in the implementation of curriculum 2013 at State Junior High School 8 Yogyakarta. This study used descriptive qualitative approach. The subjects of this study were personnels related to the implementation of curriculum 2013 in instructional implementation of State Junior High School 8 Yogyakarta consisting of the principal, vice principal in curriculum affairs, teachers, and students. Data collection was conducted through participant observation, in-depth interviews, and documentation. The data were validated by means of perseverance observation, data triangulation, and data checking. The data were analyzed continually since the beginning of data collection, and passed three stages, namely: data reduction, data presentation, and drawing conclusions. The research results reveal that: (1) Instructional planning is conducted by translating ideas and concepts of Curriculum 2013 first, then lesson plans can be drafted and developed in detail from a certain subject matter or theme which is referred to the content standard and syllabus; (2) The instruction is conducted using a scientific approach; (3) The assessment of the learning outcome was conducted using both written and verbal tests, and also non-test technique, performance observation, and behavior measurement.
\end{abstract}

Keywords: one or more word(s) or phrase(s), that it's important, spesific, or representative for the article 


\section{Pendahuluan}

Pengembangan Kurikulum 2013 sangat erat berkaitan dengan kurikulum sebelumnya, yaitu kurikulum Tingkat Satuan Pendidikan (KTSP). Kurikulum yang menggunakan pendekatan terpusat pada bidang studi (subject-centered curriculum) ini sejak 2006 telah diterapkan di sekolah-sekolah seluruh Indonesia. Karakteristik KTSP ialah memilah struktur kurikulum ke dalam berbagai mata pelajaran yang dipandang perlu untuk peserta didik. Namun saat ini, kurikulum tersebut oleh pemerintah dipandang kurang mampu memenuhi kompetensi yang dibutuhkan untuk abad 21 yang dikenal sebagai abad ilmu pengetahuan dan knowledge-based society. Pada tahun 2013, pemerintah menerbitkan Permendikbud Nomor 65 yang menyatakan perlunya dilakukan perubahan Standar Proses Pendidikan Dasar dan Menengah, serta sistem pembelajaran dan sistem penilaian sebagai implikasi dari perubahan pada standar proses tersebut (Mendikbud RI, 2013b).

Tema pembaharuan dan perbaikan pada Kurikulum 2013 yaitu ingin menciptakan manusia Indonesia yang mampu berpikir kreatif, produktif, inovatif, proaktif, dan afektif, melalui pengembangan sikap (tahu mengapa), keterampilan (tahu bagaimana), dan pengetahuan (tahu tentang apa) secara integratif. Pengintegrasian ini merupakan salah satu upaya untuk memperbaiki peringkat Indonesia berdasarkan studi TIMSS (Trends in International Mathematics and Science Study) dan Program for International Student Assessment (PISA), dimana pada 2011 peserta didik hanya mampu sampai level 3 dari 6 (enam) level kemampuan kognitif yang berkaitan dengan kemampuan berpikir tingkat tinggi (berpikir kritis, berpikir kreatif, analitis, sistematis dan logis untuk menemukan alternatif pemecahan masalah melalui eksplorasi data secara empiris dalam rangka menumbuhkan sikap ilmiah). Begitu juga kemampuan siswa Indonesia dalam memahami informasi yang kompleks, pemecahan masalah, pemakaian alat, prosedur, pemecah- an masalah dan melakukan investigasi yang masih berada rendah dan perlu ditingkatkan.

Untuk itu, salah satu pendekatan pembelajaran yang dipandang tepat untuk mengintegrasikan ketiga aspek di atas, ialah dengan dimensi pedagogik modern dalam pembelajaran, yaitu menggunakan pendekatan saintifik. Pendekatan saintifik adalah pendekatan pembelajaran yang dilakukan melalui proses mengamati (observing), menanya (questioning), mencoba (experimenting), menalar (associating), dan mengkomunikasikan (communication) (Fadlillah, 2014, p. 175). Definisi lain menyatakan bahwa the scientific method is an approach to data collection that relies on two assumptions: (1) Knowledge about the world is acquired through observation, and (2) the truth of the knowledge is confirmed by verification--that is, by others making the same observations (Keyes, 2010, p. 21). Berdasarkan berbagai definisi tersebut, dapat disimpulkan bahwa pendekatan pembelajaran saintifik ialah pola pembelajaran yang mendorong siswa agar belajar secara aktif dengan mencurahkan segenap pikirannya secara kritis, analitis, dalam memecahkan masalah pembelajarannya dengan cara mengamati, menanya, mencoba, menalar, menyaji, dan menciptakan.

Selain hal tersebut, pendekatan saintifik ini dipandang relevan dengan tiga teori belajar, yaitu teori Bruner, teori Piaget, dan teori Vygotsky. Bruner sendiri teorinya dikenal dengan teori belajar penemuan (Hosnan, 2014, p. 35). Oleh sebab itu banyak kalangan menilai bahwa pemilihan pendekatan saintifik pada Kurikulum 2013 dianggap tepat, karena pendekatan ini cocok bagi pemenuhan rasa ingin tahu siswa, sehingga proses pembelajaran memiliki kebermaknaan yang tinggi (Daryanto, 2014, p. 60).

Selain proses pembelajaran, sistem penilaian juga dikembangkan. Sistem penilaian pada Kurikulum 2013 diatur dalam Permendikbud Nomor 66 Tahun 2013 di mana guru dan satuan pendidikan wajib mengevaluasi hasil belajar siswa secara komprehensif, menyeluruh, komplek, dan 
valid (Mendikbud RI, 2013a). Salah satu alat ukur yang digunakan ialah penilaian autentik. Penilaian autentik yaitu penilaian yang melibatkan siswa di dalam tugas-tugas autentik yang bermanfaat, penting dan bermakna yang selanjutnya dapat dikatakan sebagai penilaian performa (Abidin, 2013, p. 81). Dalam definisi yang lain disebutkan bahwa, penilaian autentik adalah kegiatan menilai peserta didik yang menekankan pada apa yang seharusnya dinilai, baik proses maupun hasil dengan berbagai instrument penilaian yang disesuaikan dengan tuntutan kompetensi yang ada di standar kompetensi (SK) atau kompetensi inti (KI) dan kompetensi dasar (KD) (Kunandar, 2013, p. 35).

Perubahan lain dalam Kurikulum 2013 terdapat pada elemen standar isi. Kurikulum 2013 menghapus istilah Standar Kompetensi mata pelajaran, yang sebelumnya digunakan dalam KTSP, diganti dengan istilah Kompetensi Inti. Mata pelajaran tidak lagi disajikan secara terpisah, akan tetapi terintegrasi dalam bentuk tema (SD dan SMP). Berdasarkan hal itu Kurikulum 2013 dikatakan sebagai integrated curriculum ialah kurikulum yang meniadakan batas-batas antara berbagai mata pelajaran dan menyajikan bahan pelajaran dalam bentuk unit atau keseluruhan (Nasution, 2003, p. 196).

Sehubungan dengan perubahan pendekatan pembelajaran dan penilaian di atas, implementasi Kurikulum 2013 tidak semudah dikatakan. Penyempurnaan kurikulum yang dibarengi dengan perubahan struktur mata pelajaran, perubahan sistem pembelajaran, dan perubahan sistem penilaian selalu berhubungan dengan berbagai aspek dalam sistem pendidikan. Guru, kepala sekolah, waktu, sumber belajar, dan sarana prasarana sekolah merupakan unsur yang berkaitan langsung dengan penerapan Kurikulum 2013. Jika perubahan kurikulum tidak dibarengi dengan perbaikan sarana prasarana, akses sumber belajar yang mudah dan berkualitas, dan peningkatan kompetensi serta perubahan mindset guru, maka upaya peningkatan mutu pen- didikan hanya sia-sia belaka. Sebagaimana dijelaskan Lie (2012) bahwa keberhasilan suatu kurikulum merupakan proses panjang, mulai dari kristalisasi berbagai gagasan dan konsep ideal tentang pendidikan, perumusan desain kurikulum, serta sarana dan prasarana, tata kelola pelaksanaan kurikulum, termasuk pembelajaran, penilaian pembelajaran, dan persiapan pendidik dan tenaga kependidikan.

Salah satu sekolah yang mendapatkan mandat dari Kemendikbud agar tetap melaksanakan Kurikulum 2013 ialah SMP Negeri 8 Yogyakarta. Sekolah ini merupakan satu di antara lima sasaran pengembangan dan percontohan Kurikulum 2013 khususnya di kota Yogyakarta. Lokasi sekolah terletak di Jl. Prof. Dr. Kahar Muzakir No 2. Sejak awal penerapannya, SMP Negeri 8 Yogyakarta mendapatkan kepercayaan penuh dari Menteri Pendidikan dan Kebudayaan untuk melaksanakan Kurikulum 2013.

Sedangkan untuk sarana dan prasarana, SMP Negeri 8 Yogyakarta ditunjang oleh sarana dan prasarana yang cukup memadai. Selain ruang kelas, fasilitas lain yang dimiliki sekolah dalam mendukung pembelajaran adalah: 1 perpustakaan, 1 Lab. IPA, 2 Lab Bahasa, 1 Lab. Komputer, 1 Lab. Biologi, 1 Lab. Multimedia, 1 ruang keterampilan, 1 ruang musik, 1 ruang agama Nasrani, 1 gedung olahraga, 1 buah panggung terbuka, dan 1 ruang server. Jumlah ruang yang digunakan untuk ruang kelas ada 29 ruangan, terdiri dari kelas VII (10 kelas), kelas VIII (10 kelas), dan kelas IX (9 kelas) dengan tiap kelas maksimal diisi 30 siswa. Untuk menciptakan pembelajaran yang efektif, sekolah memiliki tenaga pendidik atau guru sebanyak 52 orang.

Selain fasilitas yang memadai, sekolah memdapat nilai akredatasi A, melaksanakan Kurikulum 2013 lebih dari dua semester, SMP Negeri 8 Yogyakarta juga pernah menjadi salah satu Rintisan Sekolah Bertaraf Internasional (RSBI) di Yogyakarta sebelum akhirnya Mahkamah Konstitusi membubarkannya dengan alasan sekolah bertaraf internasional bertentangan dengan 
UUD 1945. Selain itu, RSBI dianggap menimbulkan dualisme pendidikan, menimbulkan adanya diskriminasi pendidikan, pembedaan antara RSBI/SBI dengan non RSBI/SBI menimbulkan adanya kastanisasi pendidikan.

Jika mengacu pada prestasi yang diraih, pemerintah, dalam hal ini Kemendikbud, tidak salah memilih SMP Negeri 8 Yogyakarta sebagai sekolah percontohan dan pengembangan Kurikulum 2013. Berbagai syarat yang mendukung terhadap berhasil dan tidaknya pelaksanaan Kurikulum 2013 telah dimiliki oleh sekolah seperti; input sekolah (SDM yang baik), fasilitas pembelajaran, sarana-prasarana, dan guruguru yang kompeten. Salain itu, salah satu dari guru SMP Negeri 8 Yogyakarta ditunjuk oleh Dinas Pendidikan menjadi salah satu fasilitator pelatihan dan pendampingan Kurikulum 2013. Keberadaan guru fasilitator tersebut di sekolah dapat membantu guru-guru lainnya untuk melaksanakan Kurikulum 2013 sebaik mungkin.

Kemudian pertanyaannya sekarang, dengan prestasi dan mutu sekolah yang baik tersebut, apakah pelaksanaan Kurikulum 2013 di SMP Negeri 8 berjalan dengan baik? Apakah ada kesulitan atau kendala bagi guru dalam melaksanakan pembelajaran saintifik, tematik integratif, dan penilaian autentik? Sudah layak kah SMP Negeri 8 Yogyakarta dijadikan prototipe implementasi Kurikulum 2013?

Berangkat dari pertanyaan dan beberapa uraian tersebut, sangat menarik apabila hal tersebut dikaji secara mendalam perihal pelaksanaan pembelajaran saintifik, penilaian autentik dan mengetahui problematika dalam penerapan Kurikulum 2013 di SMP Negeri 8 Yogyakarta. Oleh karenanya dalam penyusunan tesis ini penulis mengangkat judul "Implementasi Kurikulum 2013 dalam Pelaksanaan Pembelajaran di SMP Negeri 8 Yogyakarta".

Berdasarkan uraian pada latar belakang, maka penelitian ini bertujuan untuk mendeskripsikan: (1) perencanaan pembelajaran; (2) pelaksanaan pembelajaran; (3) pelaksanaan penilaian; dan (4) faktor peng- hambat dan pendukung pelaksanaan pembelajaran dalam rangka mengimplementasikan Kurikulum 2013 di SMP Negeri 8 Yogyakarta.

\section{Metode Penelitian}

Penelitian ini merupakan penelitian deskriptif dengan desain kualitatif. Menurut (Sukmadinata, 2012, p. 72) penelitian deskriptif adalah penelitian yang berusaha mendeskripsikan fenomena yang ada, baik fenomena yang bersifat alamiah atau rekayasa manusia. Sedangkan kualitatif merupakan penelitian yang menghasilkan teori yang timbul dari data bukan hipotesis. Penelitian deskriptif kualitatif yang dimaksud adalah dengan menghimpun data atau informasi sebanyak-banyaknya, bersifat deskriptif, lebih mementingkan proses daripada hasil, membatasi studi dengan fokus, memiliki seperangkat kriteria untuk memeriksa keabsahan data, rancangan penelitiannya bersifat sementara dan hasil penelitiannya disepakati oleh kedua pihak, baik oleh peneliti dan subjek penelitian.

Pemilihan pendekatan penelitian ini didasarkan atas pertimbangan bahwa data yang hendak dicari adalah data yang menggambarkan implementasi Kurikulum 2013 untuk tataran tingkat sekolah kemudian diperdalam pada implementasi kurikulum tingkat kelas yaitu pada pelaksanaan pembelajaraannya yang dimulai dari proses perencanaan, pelaksanaan, dan penilaian hasil belajar di SMP Negeri 8 Yogyakarta.

Penelitian ini dilaksanakan di SMP Negeri 8 Yogyakarta. Penelitian ini dilaksanakan mulai bulan Agustus 2015 (untuk pra-survei) dan bulan September 2015 (penelitian) hingga titik keajegan pada bulan Desember 2015. Dalam penelitian ini yang menjadi subjek penelitian adalah personel yang berkaitan dengan implementasi Kurikulum 2013 dalam pelaksanaan pembelajaran di SMP Negeri 8 Yogyakarta antara lain: kepala sekolah, waka kurikulum, fasilitator dan pendamping Kurikulum 2013, masing-masing 3 orang guru matematika, 
IPA, IPS, dan bahasa Indonesia yang jumlahnya secara keseluruhan 12 orang guru mata pelajaran. Kemudian, terdapat 12 siswa yang berhasil dimintai keterangannya antara lain: 4 orang kelas VII, 4 orang kelas VIII, dan 4 orang siswa kelas IX. Objek penelitian ini adalah implementasi Kurikulum 2013 dalam pelaksanaan pembelajaran di SMP 8 Negeri Yogyakarta. Pelaksanaan pembelajaran yang dijadikan objek adalah kegiatan perencanaan, pelaksanaan, dan penilaian hasil belajar siswa yang merupakan satu kesatuan.

Dalam suatu penelitian diperlukan adanya data sebagai hasil akhir dari penelitian. Pengumpulan data yang kongkrit penulis melaksanakan beberapa teknik dan instrument pengumpulan data sebagai berikut.

Pertama, dalam penelitian ini, peneliti menggunakan teknik observasi partisipasi pasif di mana peneliti datang ke tempat kegiatan, namun tidak ikut terlibat di dalamnya. Observasi yang dilakukan pada saat proses pembelajaran berlangsung meliputi kegiatan pra-instruksional sampai kegiatan penutup. Peneliti juga melakukan observasi terhadap teknik penilaian yang digunakan oleh guru, serta kemungkinan hambatan dan upaya yang dilakukan oleh guru untuk mengatasi hambatan yang ditemui saat proses pembelajaran berlangsung.

Dalam melakukan observasi, peneliti dilengkapi lembar observasi. Lembar observasi yang digunakan dalam penelitian ini yaitu; observasi guru mengenai perencanaan pembelajaran, pelaksanaan pembelajaran, dan penilaian hasil belajar siswa serta dilengkapi dengan pedoman observasi kegiatan siswa dalam pembelajaran.

Kedua, selain menggunakan observasi, peneliti juga menggunakan wawancara. Teknik wawancara yang digunakan dalam penelitian ini menggunakan wawancara semi terstruktur. Jenis wawancara ini tergolong dalam kategori in-dept interview, yaitu dalam pelaksanaannya lebih bebas bila dibandingkan dengan wawancara terstruktur. Sebelum melakukan kegiatan wawancara, terlebih dahulu peneliti membuat pedoman wawancara dengan tujuan agar proses tetap terfokus dan tidak keluar dari kontek yang menjadi tujuan utama peneliti. Informan yang dipilih oleh peneliti dalam penelitian ini adalah kepala sekolah, waka kurikulum, pendamping Kurikulum 2013, guru, dan siswa.

Ketiga, studi dokumentasi. Studi dokumentasi digunakan untuk melengkapi penggunaan metode observasi dan wawancara dalam penelitian deskriptif. Studi dokumentasi dalam penelitian ini dilakukan untuk memperoleh data mengenai perencanaan pembelajaran, pelaksanaan pembelajaran, dan penilaian hasil belajar siswa. Dalam penelitian ini, peneliti mendokumentasikan proses pembelajaran saintifik di kelas 7, 8 dan 9. Kemudian peneliti mengambil dokumen-dokumen berupa profil sekolah, rencana pelaksanaan pembelajaran (RPP), instrument penilaian, daftar nilai dengan teknik penilaian Kurikulum 2013, dan laporan tahuan sekolah untuk memperoleh data dokumentasi.

Pengujian keabsahan data dilakukan dengan cara ketekunan/keajegan pengamatan, trianggulasi data dan auditing atau pemeriksaan data. Berkaitan dengan hal tersebut, maka langkah-langkah yang ditempuh dalam pengujian keabsahan data sebagai berikut:

Pertama, ketekunan pengamatan bermaksud menemukan ciri-ciri dan unsur-unsur dalam situasi yang sangat releven dengan persoalan atau isu yang sedang dicari dan kemudian memusatkan diri pada hal-hal tersebut secara rinci. Keajegan pengamatan diupayakan mencari secara konsisten interpretasi dengan berbagai cara dalam kaitan dengan proses analisis yang konstan dan tentatif, dengan cara mencari konsistensi apa yang dapat diperhitungkan dengan apa yang tidak dapat, agar data betul-betul valid, akurat, dan bisa dipertanggungjawabkan

Kedua, triangulasi data, yaitu memeriksa keabsahan data melaui sumber, teknik dan teori. Triangulasi sumber memungkinkan peneliti melakukan pengecekan 
ulang dan melengkapi informasi dengan sumber-sumber lainn. Triangulasi sumber dalam penelitian ini dilakukan antara kepala sekolah, guru, dan siswa. Triangulasi teknik prosesnya dengan menguji kredibilitas data yang dilakukan dengan cara mengecek data kepada sumber yang sama namun dengan teknik yang berbeda. Data yang diperoleh dengan wawancara, kemudian dicek dengan data yang diperoleh dari observasi, dan dokumentasi. Triangulasi teknik yang digunakan oleh peneliti dalam penelitian ini adalah antara observasi, wawancara dan dokumentasi. Triangulasi dengan teori digunakan untuk mempertajam analisis penelitian dengan memeriksa derajat kepercayaan data

Dalam penelitian ini analisis data dilakukan secara terus-menerus sejak awal pengumpulan data. Pada prosesnya terdiri dari atas tiga tahapan yang saling terkait yaitu reduksi data, penyajian data, dan pengambilan kesimpulan. Proses analisis data dilakukan mulai proses awal sampai dengan akhir pengumpulan.

Data-data yang telah dikumpulkan (apapun data yang terdapat di lapangan) melalui wawancara secara mendalam, observasi baik secara partisipan maupun nonpartisipan, dan analisis dokumen direduksi dengan cara:

Pertama, menyeleksi, menentukan fokus, menyederhanakan dan mentransformasikan data yang muncul pada catatan lapangan. Reduksi data yang dilakukan berupa penulisan ringkasan, penajaman, pengkodean, pemfokusan, pembuangan, dan penyusunan data sehingga kesimpulan dapat ditarik, dibuktikan, dan dipertanggungjawabkan. Data yang diperoleh juga diklasifikasikan menjadi sub-sub. Klasifikasi dalam penelitian ini, terdiri dari; perencanaan pembelajaran, pelaksanaan pembelajaran, penilaian hasil belajar dengan menggunakan penilaian autentik, dan hambatan serta kendala yang dihadapi.

Kedua, melakukan analisis data baik pada perencanaan pembelajaran, pelaksanaan pembelajaran, penilaian hasil belajar, dan hambatan, serta kendala dalam pelak- sanaan pembelajaran. Data pelaksanaan pembelajaran dianalisis berdasarkan Permendikbud Nomor 65 Tahun 2013 tentang Standar Proses Pendidikan Dasar dan Menengah, Lampiran Permendikbud Nomor 103 Tahun 2014 tentang Pembelajaran pada Pendidikan Dasar dan Pendidikan Menengah dan, juga berdasarkan teori yang ada. Setelah analisis data selesai, data disajikan dalam bentuk naratif yang mendeskripsikan perencanaan pembelajaran, pelaksanaan pembelajaran, penilaian hasil belajar, dan hambatan serta kendala dalam pelaksanaan. Kemudian dilakukan pembahasan terhadap deskripsi data. Pembahasan berusaha menemukan gambaran dan menginterpretasikan apa yang terkandung dalam perencanaan pembelajaran, pelaksanaan pembelajaran, evaluasi hasil belajar. Berdasarkan deskripsi data dan pembahasan, selanjutnya disimpulkan. Kesimpulan ini nantinya akan menjawab pertanyapertanyaan yang ada pada rumusan masalah penelitian ini.

\section{Hasil Penelitian dan Pembahasan}

\section{Hasil Penelitian}

Proses penelitian di lapangan yang tidak terlalu berjalan dengan mulus dan tidak mudah karena berbagai faktor, telah sampai pada proses akhir yaitu penyajian data. Data-data di bawah ini merupakan sekumpulan data yang diperoleh dari hasil pengamatan, observasi, wawancara dan telaah dokumen. Data-data di bawah ini tentunya sudah melalui berbagai rangkain kaidah penelitian seperti, ketekunan, keajegan pengamatan, trianggulasi data, dan auditing. Langkah-langkah tersebut kemudian dilanjutkan dengan analisis data dengan menyeleksi, menentukan fokus, menyederhanakan dan mentransformasikan data yang muncul pada catatan lapangan. Beberapa poin penting yang dianalisis ialah pada perencanaan pembelajaran, pelaksanaan pembelajaran, penilaian hasil belajar, dan hambatan serta kendala dalam pelaksanaan pembelajaran. Untuk itu, berikut hasil data-data implementasi Kuriku- 
lum 2013 di SMP N 8 Yogyakarta dalam pembelajaran setelah melalui serangkaian proses analisis tersebut.

Perencanaan Pembelajaran

Dalam hal perencanaan pembelajaran, data-data yang diperoleh adalah sebagai berikut:

Pertama, semua guru di SMP Negeri 8 Yogyakarta menyusun RPP untuk mata pelajaran yang diampunya. Pengembangan RPP dikembangkan atau disusun di setiap awal semester atau awal tahun pelajaran. Hal ini ditujukan agar RPP telah tersedia terlebih dahulu dalam setiap awal pelaksanaan pembelajaran.

Kedua, pengembangan RPP oleh guru SMP Negeri 8 Yogyakarta dilakukan secara mandiri dan secara bersama-sama melalui musyawarah guru mata pelajaran (MGMP). Di antara kegiatan penyusunan RPP yang dilakukan bersama musyawarah guru mata pelajaran antara lain; kegiatan pengkajian silabus dengan mengkaji KI dan $\mathrm{KD}$, mengkaji materi pembelajaran, mengkaji proses pembelajaran, mengkaji penilaian pembelajaran, mengkaji alokasi waktu, dan mengkaji sumber belajar.

Ketiga, dalam merumuskan indikator yang di dalamnya terdapat kegiatan merumuskan indikator pencapaian kompetensi KD pada KI-1, merumuskan indikator pencapaian kompetensi KD pada KI-2, merumuskan indicator pencapaian kompetensi KD pada KI-3, dan merumuskan indicator pencapaian kompetensi KD pada KI-4 dirumuskan bersama dalam musyawarah guru mata pelajaran (MGMP).

Keempat, berbagai persoalan keterlambatan pendistribusian buku pegangan guru dan buku pegangan siswa serta persoalan kesalahan konsep dan kedangkalan materi Kurikulum 2013 menjadikan buku K-13 bukan sebagai sumber rujukan utama dalam proses pembelajaran di dalam kelas. Kemudian untuk mengembangkan materi pelajaran, guru-guru bersama siswa mengembangkan materi pelajaran selain dari buku teks pelajaran dan buku panduan guru juga dikembangkan dari sumber Internet, alam sekitar, ahli/professional, dan berbagai sumber belajar yang lainnya (museum, ritel, dan tempat-tempat bersejarah).

Kelima, RPP yang dibuat mengedepankan perencanaan pembelajaran yang nantinya dalam proses belajar mengajar akan mendorong partisipasi aktif siswa. RPP yang dibuat selalu berusaha agar tidak menyimpang dari tujuan Kurikulum 2013 yaitu dengan menggunakan pendekatan saintifik. Proses pembelajaran dilakukan bertujuan untuk menghasilkan siswa yang mandiri dan tidak berhenti belajar, proses pembelajaran yang berpusat pada siswa (student centered) sehingga dapat mengembangkan motivasi, minat, rasa ingin tahu (curiousity), kreativitas, inisiatif, inspirasi, kemandirian, semangat belajar, keterampilan belajar dan kebiasaan belajar.

Keenam, di dalam menentukan alokasi waktu untuk setiap KD didasarkan pada jumlah minggu efektif dan alokasi waktu mata pelajaran setiap minggu yang tersedia dengan tetap mempertimbangkan jumlah KD, keluasan, kedalaman, tingkat kesulitan, dan tingkat kepentingan KD. Alokasi waktu yang dirinci dalam RPP mengacu pada yang dituliskan.

Ketujuh, guru-guru SMP Negeri 8 Yogyakarta mengembangkan sendiri penilaian pembelajaran dengan menentukan lingkup, teknik, dan instrument penilaian. Selain itu juga, guru-guru dengan sendirinya mengembangkan pedoman penskoran yang akan digunakan menilai hasil belajar siswa.

Kedelapan, pengembangan RPP di SMP 8 Yogyakarta tidak pakem. Guru-guru diberikan kebebasan berkreasi sesuai dengan ide dan kreatifitasnya. Kepala sekolah menyarankan untuk mengambil semangat implemintas Kurikulum 2013 daripada guru-guru disibukkan menyiapkan perangkat pembelajaran dan penilaian yang dianggap terlalu administratif dan menyita banyak waktu guru. Dalam prosesnya, Kepala sekolah SMP Negeri 8 Yogyakarta lebih mengutamakan kualitas pelaksanaan dan hasil daripada kualitas perencanaan. 
Pelaksanaan Pembelajaran

Dalam hal pelaksanaan pembelajaran, data-data yang diperoleh adalah sebagai berikut.

Pertama, guru memfasilitasi siswa memunculkan gagasan baru. Dari beberapa kegiatan yang teramati di lapangan, tampak usaha-usaha yang dilakukan guru menfasilitasi siswa agar berani memunculkan gagasan baru. Misalnya, salah satu usaha yang dilakukan dengan mengajak siswa melakukan observasi di luar lingkungan sekolah dan memberikan keleluasaan kepada siswa dalam mengembangkan sumber belajar. Usaha ini dilakukan oleh guru untuk menyediakan peluang kepada siswa belajar dari tujuan yang ditetapkan dan mengembangkan ide-ide secara lebih luas. Siswa dapat mengembangkan idenya dari internet, jurnal, majalah, dan sumber lainnya yang lebih variatif.

Salah satu upaya lainnya yang dilakukan guru dalam kegiatan pembelajaran ialah dengan mendukung kemandirian siswa belajar dan berdiskusi, membuat hubungan, merumuskan kembali ide-ide, dan menarik kesimpulan sendiri. Kegiatan ini tampak dari kegiatan siswa menalar dan mengkomunikasikan hal yang sudah dipelajari. Upaya-upaya seperti ini jarang ditemukan dalam kegiatan pembelajaran masa lalu. Dan, usaha ini sangat berarti terhadap perkembangan siswa kedepannya.

Kedua, guru menyampaikan materi dengan mudah difahami, menarik, dan menyenangkan. Meskipun tidak secara keseluruhan, dari hasil pengamatan ditemukan banyak guru SMP Negeri 8 Yogyakarta yang mengusahakan sebuah kegiatan pembelajaran yang menarik, menyenangkan, dan mudah difahami. Usaha ini tampak dari upaya guru dalam memberikan memotivasi selama kegiatan pembelajaran. Dari hasil pengamatan peneliti, guru selalu menggunakan kata-kata motivasi untuk menambah semangat dan etos belajar siswa.

Usaha lainnya untuk menciptakan pembelajaran yang menyenangkan, tam- pak dari usaha guru dalam menghadirkan media dan sumber belajar yang variatif. Salah satu contohnya ialah usaha yang dilakukan oleh guru IPS ketika memutar video pembelajaran tentang kondisi sosial dan ekonomi masyarakat. Dari hasil pengamatan, tampak terlihat keseriusan siswa dalam menyimak tayangan dan mencatat setiap momen yang dianggap penting oleh siswa. Begitupun juga usaha yang dilakukan oleh guru bahasa Indonesia dalam kegiatan pembelajaran sebagaimana yang ditemui di dalam pengamatan. Berbagai sumber belajar yang disediakan untuk kegiatan pembelajaran bahasa Indonesia seperti halnya Koran, Jurnal, dan Majalah berhasil menarik perhatian dan motivasi siswa selama kegiatan pembelajaran.

Ketiga, Guru menggunakan beragam strategi pembelajaran. Berdasarkan hasil wawancara dengan kepala sekolah SMP Negeri 8 yogyakarta, sekolah memberikan kesempatan seluas-luasnya kepada guru untuk mengembangkan strategi pembelajaran yang sesuai dengan karakteristik setiap mata pelajaran yang mereka ajarkan. Sekolah tidak membatasi guru menggunakan strategi tertentu. Sebab dengan menggunakan pendekatan saintifik, tentunya guru sudah memahami strategi pembelajaran yang sesuai dengan pendekatan tersebut (15/12/2015).

Dari hasil pengamatan peneliti di dalam kelas, dan juga berdasarkan dokumen RPP yang dirancang dan dirumuskan ada banyak strategi yang digunakan oleh guru. Beberapa strategi tersebut diantaranya ialah projek base learning, pembelajaran kontekstual, dan pembelajaran koperatif. Untuk strategi pembelajaran koperatif misalnya, sering ditemukan dalam pengamatan peneliti di dalam kelas, baik dalam kegiatanbelajar-mengajar matematika, IPA, maupun IPS.

Pada kesempatan yang lain, wawancara dilakukan dengan waka kurikulum. Dalam sebuah wawancaranya dinyatakan bahwa, untuk menentukan strategi pembelajaran, sekolah memberikan wewenang penuh pada guru dalam menentukan 
strategi pembelajaran yang mereka gunakan dalam pembelajaran. Sekolah hanya mengatur waktu/memberikan waktu kepada guru dalam proses pembelajaran, namun dalam praktiknya di kelas, guru diberikan kebebasan penuh.

Keempat, guru menggunakan beragam media pembelajaran. Penggunaan media pembelajaran tampak dari kegiatankegiatan pembelajaran di atas. Beberapa diantaranya seperti pada kegiatan pendahuluan, siswa mengamati, mengumpulkan informasi, dan kegiatan siswa dalam mengkomunikasikan hasil belajarnya.

Penggunaan media pembelajaran dalam setiap kegiatan pembelajaran di SMP Negeri 8 Yogyakarta menjadi sebuah keharusan bagi guru-guru. Meskipun terkadang dalam kondisi tertentu dari hasil pengamatan peneliti, masih terdapat guru yang minimalis dalam memanfaatkan media pembelajaran, misalnya hanya berupa papan tulis dan alat peraga sederhana lainnya. Akan tetapi, hal ini persentasenya lebih sedikit daripada guru yang memanfaatkan media.

Dalam sebuah wawancaranya dengan wakil kepala sekolah SMP Negeri 8 Yogyakarta perihal media pembelajaran disampaikan bahwa, SMP Negeri 8 mengintruksikan kepada semua guru-guru agar benar-benar mengoptimalkan media pembelajaran untuk kegiatan pembelajaran. Guru dituntut agar lebih familiar dengan teknologi untuk pembelajaran, termasuk diantaranya Teknologi Informasi dan Komunikasi (TIK). Pemanfaatan teknologi informasi dan komunikasi (TIK) untuk meningkatkan efisiensi dan efektivitas pembelajaran. Maka dari itu, sekolah selalu mengupayakan agar pemanfaatan TIK menjadi budaya guru dan siswa.

Dalam kesempatan yang berbeda, wawancara juga diberikan kepada RW selaku guru matematika kelas VII. Dalam sebuah wawancaranya yang dilakukan pada tanggal 10 November 2015, Ia mengatakan bahwa, mengajar tanpa media ibarat orang makan nasi tampa garam, semuanya akan jadi hambar. Begitupun juga dengan kegiatan pembelajaran, mengajar tanpa memanfaatkan media membuat proses pembelajaran menjadi kurang efektif. Oleh karena itu menurutnya, media menjadi keharusan dan keniscayaan bagi seorang guru, termasuk diantaranya dapat menguasai TIK. Sebab, mendapatkan pelajaran dengan dukungan TIK atau tidak siswa tetap akan menghadapi tantangan dalam hidupnya menjadi pengguna TIK. Jika sekolah tidak memfasilitasi pasti daya kompetisi siswa akan jomplang daripada siswa yang memperoleh pelajaran menggunakannya.

Kelima, guru menggunakan beragam sumber belajar lain. Dari hasil pengamatan peneliti untuk beberapa kegiatan pembelajaran yang diamati, tampak proses pembelajaran tidak lagi bergantung pada guru sebagai sumber utama atau sumber tunggal dalam kegiatan pembelajaran. Proses pembelajaran tidak lagi berbentuk proses komunikasi verbal antara guru dan siswa. Siswa diberikan kesempatan menjadi sumber belajar untuk kegiatan pembelajaran di dalam kelas. Hal ini tampak ketika guru mengarahkan dan menganjurkan agar siswa menggali referensi materi pelajaran dari berbagai sumber, mulai dari buku teks pelajaran, sumber online, hingga memperoleh langsung dari ahlinya/ maestro-nya.

Dari beberapa sumber yang diperoleh, siswa diarahkan dan dimotivasi agar berani menyampaikan temuan-temuannya baik di depan kelas maupun ditengah-tengah temannya. Misalnya guru memberikan tugas individu mempresentasikan sebuah makalah berkaitan dengan materi yang akan dipelajari atau membuat diskusi kelompok dengan menghadirkan berbagai sumber sebagai dasar bahan diskusi. Kondisi seperti ini, serinkali teramati oleh peneliti dalam kegiatan observasi atau pengamatan di dalam kelas.

Keenam, guru memfasilitasi peserta didik untuk memperoleh pengalaman yang bermakna. Ada beberapa upaya guru agar siswa tidak hanya tahu hal-hal yang bersifat abstrak. Beberapa diantara upaya itu 
ialah; (1) melibatkan peserta didik mencari informasi yang luas dan dalam tentang topik/tema materi yang akan dipelajari, (2) menggunakan pendekatan pembelajaran saintifik, (3) menghadirkan beragam media pembelajaran dan sumber belajar lain, (4) memfasilitasi terjadinya interaksi antar peserta didik serta antara peserta didik dengan guru, lingkungan, dan sumber belajar lainnya, (5) melibatkan peserta didik secara aktif dalam setiap kegiatan pembelajaran, (6) memfasilitasi peserta didik melakukan percobaan di laboratorium, studio, dan lapangan.

\section{Penilaian Hasil Belajar}

Dari beberapa kali peneliti melakukan pengamatan di dalam kelas, guru selalu mengupayakan diri mencatat dan mengamati satu persatu sikap siswa dengan menggunakan pedoman observasi yang berisi sejumlah indikator. Ketika di akhir pelajaran, guru tidak lupa melakukan tes untuk mengetahui keberhasilan siswa dalam mengikuti pelajaran. Tes ini terkadang berupa Quis dan terkadang pula meminta siswa menjelaskan hubungan antara materi yang dipelajari dengan kehidupan sehari-hari.

Menurut Kepala Sekolah SMP Negeri 8 Yogyakarta, sejauh ini sekolah telah mengupayakan penilaian hasil belajar siswa sesuai dengan Permendikbud No. 66 Tahun 2013 tentang standar penilaian. Menurutnya, penilaian yang dilakukan sekolah sudah didasarkan pada prinsip objektif, terpadu, ekonomis, transparan, akuntabel dan edukatif. Dengan demikian, penilaian yang dilakukan oleh guru SMP Negeri 8 Yogyakarta tidak hanya dilakukan di akhir periode pembelajaran tetapi dilakukan bersama (simultan) dan merupakan kegiatan yang tidak terpisahkan dalam pembelajaran.

Berkaitan dengan hasil wawancara tersebut, kemudian peneliti mencoba melakukan observasi dan pengamatan di dalam kelas untuk mengetahui kondisi riil terkait aktivitas guru dalam menilai proses dan hasil belajar siswa. Pengamatan dilakukan dalam kegiatan belajar-mengajar untuk materi Matematika, IPA, IPS, dan bahasa Indonesia. Berikut deskripsi hasil pengamatan tersebut berdasarkan katakori penilaian sikap, penilaian pengetahuan, dan penilaian keterampilan.

Pertama, penilaian kompetensi sikap. Dalam sebuah observasi dan pengamatan peneliti dalam kegiatan belajarmengajar pelajaran matematika, IPA, IPS, dan bahasa Indonesia di sela-sela kegiatan mengajar guru selalu mengamati dan mengobservasi satu persatu aktivitas siswa dalam kegiatan pembelajaran. Guru melihat dan mencatat sikap siswa baik sikap spiritual maupun sikap sosial. Selain melalui observasi dan pengamatan tentang hal-hal yang tampak dari sikap siswa, penilaian kompetensi sikap juga dengan menggunakan penilaian diri, penilaian "teman sejawat" oleh peserta didik dan jurnal. Instrumen yang digunakan untuk observasi, penilaian diri, dan penilaian antarpeserta didik adalah daftar cek atau skala penilaian (rating scale) yang disertai rubrik, sedangkan pada jurnal berupa catatan pendidik.

Kedua, penilaian kompetensi pengetahuan. Setelah hasil observasi dan pengamatan peneliti tentang penilaian sikap dideskripsikan, kemudian selanjutnya adalah penilaian pengetahuan. Penilaian pengetahuan secara umum dimaknai sebagai penilain potensi intelektual yang terdiri dari tahapan mengetahui, memahami, menerapkan, menganalisis, mensintesis, dan mengevaluasi. Oleh karena itu, observasi dan pengamatan peneliti untuk penilaian pengetahuan ialah tentang hal-hal yang dilakukan guru dalam rangka untuk mengetahui pencapaian kompetensi pengetahuan peserta didik.

Dari hasil observasi dan pengamatan peneliti untuk kegiatan pembelajaran matematika, guru menggunakan ragam instrument untuk menilai kemampuan siswa dalam memahami pelajaran. Beberapa instrument yang digunakan ialah tes tulis berupa uraian dan mencocokkan atau 
pilihan ganda, tes lisan, dan penugasan secara kelompok maupun individual.

Untuk tes lisan digunakan setelah serangkaian kegiatan pembelajaran selesai atau sebelum guru mengakhiri kegiatan pembelajaran. Tes lisan ini biasanya guru menyebutnya dengan Quis. Tekniknya ialah guru membuat soal sebanyak 10 soal yang kemudian siswa diminta menjawab secara kompetitif. Penilaian dengan mempertimbangkan kecepatan dan ketepatan dalam menjawab soal. Dalam artian, siswa yang paling cepat dan benar menjawabnya, dia yang mendapatkan nilai.

Selain tes lisan, guru juga menggunakan tes tulis. Tes tulis yang sering digunakan ialah dengan uraian. Jumlah butir soal yang harus dijawab oleh siswa paling banyak 10 butir soal. Tes uraian jenisnya ada dua yang sering digunakan oleh guru yaitu, tes uraian yang menuntut pekerjaannya di dalam kelas, dan juga tes uraian yang husus dikerjakan di rumah (PR).

Kemudian juga guru menggunakan tugas projek untuk menilai kemampuan pengetahuan siswa. Dari hasil telaah dokumen penilaian pengetahuan, guru menggunakan tes projek sebanyak 2 kali selama satu semester. Tugas projek ini selain bentuk tugasnya secara individual juga dikerjakan berkelompok. Waktu pelaksanaanya maksimal satu minggu, dan hasil tugas proyek dipresentasikan di depan kelas.

Ketiga, selain kompetensi sikap dan pengetahuan yang dinilai, guru juga melakukan penilaian kompetensi keterampilan. Menurut pengakuan waka kurikulum SMP Negeri 8 Yogyakarta pada tanggal 10 November 2015, guru menilai kompetensi keterampilan siswa melaui penilaian kinerja dimana siswa dituntut mendemonstrasikan suatu kompetensi tertentu melalui tes praktek, projek, dan penilaian fortofolio. Hal yang dinilai dari siswa oleh guru ialah berupa keterampilan melakukan suatu aktivitas atau perilaku sesuai dengan kompetensinya, dilakukan dengan perencanaan, pelaksanaan dan pelaporan hasil praktek.

Pada kesempatan yang berbeda, wawancara dilakukan dengan kepala seko- lah SMP Negeri 8 Yogyakarta. Wawancara dilakukan berkenaan dengan penilaian kompetensi keterampilan. Dalam sebuah wawancaranya, kepala sekolah mengatakan bahwa penilaian keterampilan dilakukan bertujuan untuk mengetahui capain kompetensi peserta didik untuk setiap mata pelajaran, sehingga guru dapat mengambil langkah-langkah strategis untuk menyempurnakan pembelajaran berikutnya.

\section{Faktor Penghambat}

Berdasarkan hasil wawancara dan observasi pada saat pelaksanaan dan penilaian pembelajaran Kurikulum 2013 di SMP Negeri 8 Yogyakarta, ditemukan beberapa hambatan. Berikut ini adalah hambatan-hambatan yang berdampak terhadap kurang maksimalnya pelaksanaan pembelajaran Kurikulum 2013 di sekolah.

Pertama, tematik terpadu kurang pas dengan pelajaran IPA. Salah satu keluhan yang disampaikan oleh Guru ialah kurang cocoknya pembelajaran tematik diterapkan pada pelajaran IPA. Menurut Ibu Narti, pembelajaran IPA selama ini dikenal dengan pembelajaran "bersyarat", Artinya, sebelum siswa mempelajari topik tertentu, siswa terlebih dahulu harus mempelajari topik pengantarnya. Jika tidak demikian, maka sulit siswa untuk mendapatkan pemahaman yang utuh, dan mendapatkan kesimpulan yang baik.

Kedua, materi banyak, namun alokasi waktu sedikit. Pembelajaran terpadu ternyata tidak membuat pembelajaran di dalam kelas menjadi sederhana, justru bagi guru-guru SMP N 8 lebih rumit. Dari hasil wawancara dengan Bapak Kamto, Guru IPS kelas VIII menyatakan bahwa, pendekatan tematik terpadu membuat pelajaran terlalu luas. Pengintegrasian pengetahuan dengan mengaitkan satu topik tertentu dengan topik yang lain dalam satu tema membutuhkan waktu dan refrensi yang banyak. Sedangkan alokasi waktu yang disediakan dalam buku pedoman K-13 terlalu sempit. Banyaknya waktu tidak sama dengan banyaknya materi yang harus disam- 
paikan. Akhirnya, tujuan utama dari pembelajaran tematik terpadu agar pengetahuan siswa diperoleh secara utuh (holistic), bermakna, dan tidak terpisah-pisah, masih jauh dari harapan.

Ketiga, banyaknya ditemukan kesalahan pada isi atau konten dalam buku K13. Dari hasil wawancara dengan Ibu Narti, banyak ditemukan kesalahan konsep, ketidak sesuaian isi, dan kurang pasnya isi materi buku pedoman K-13. Kesalahan konsep tersebut menurutnya, akan berdampak sangat fatal dan dapat menyesatkan. Misalnya, bagi Guru IPA yang berlatar belakang Fisika, bisa jadi tidak akan mengetahui bahwa dalam buku biologi terdapat konsep dan isi materi yang salah, begitupun juga sebaliknya. Sehingga, Guru-Guru SMP N 8 Yogyakarta menyimpulkan bahwa, penyusun buku K-13 tidak memahami secara benar apa yang dibuat.

Keempat, penambahan materi terlalu banyak. Selain merasa disibukkan dengan penilaian, pendekatan pembelajaran, Guru-Guru juga mengeluh tentang penambahan materi untuk kelas VIII. Menurut Ibu Narti Guru IPA Kelas VIII, menyatakan bahwa kurang lebih ada sekitar tiga Bab yang semestinya dipelajari di kelas IX ditambahkan ke kelas VIII. Keluhan ini ditambah dengan minimnya waktu yang disediakan. Sebab, penambahan materi dengan menyelipkan materi kelas IX ke kelas VIII, tidak disertai dengan penambahan jam pelajaran. Sehingga guru-guru merasa kesulitan menyesuaikan materi yang banyak dengan waktu yang terbatas.

Kelima, keterlambatan buku pegangan siswa dan buku pegangan guru. Keterlambatan pendistribusian buku dan kesalahan pendistribusian yang sering terjadi membuat guru-guru kebingungan mengimplementasikan K-13. Akhirnya pengembangan materi ajar tidak maksimal.

\section{Faktor Pendukung}

Untuk mendukung implementasi K-13 ada beberapa hal yang dikembangkan oleh sekolah, diantaranya ialah pengem- bangan muatan lokal. Muatan lokal yang diterapkan di SMP N 8 Yogyakarta terbagi menjadi dua yaitu untuk program prakarya Kurikulum 2013 dan program reguler. Untuk program prakarya Kurikulum 2013 meliputi seni tari dan batik yang merupakan ciri khas has budaya yang harus dikembangkan dan dipertahankan. Di samping itu, kedua muatan lokal tersebut merupakan potensi dan keunggulan Daerah Istimewa Yogyakarta dalam menghadapi kompetisi Masyarakat Ekonomi Asia (MEA), dimana semua elemen masyarakat termasuk lembaga pendidikan diharapkan memiliki ciri khas yang dapat dibanggakan dan berbasis pada kearifan lokal.

Selain itu pula, program prakarya tersebut diharapkan ikut membentuk karakter peserta didik agar tidak latah pada arus perkembangan teknologi dan informasi yang sangat cepat, yang hanya bangga terhadap produk dan budaya bangsa lain dan di sisi lain melupakan akar budaya dan produk bangsa sendiri. Penerapat muatan lokal prakarya seni tari dan batik di SMP N 8 Yogyakarta juga mengacu pada peraturan daerah kota Yogyakarta Nomor 5 tahun 2008 tentang Sistem Penyelenggaraan Pendidikan. Selain beberapa program tersebut, SMP N 8 Yogyakarta juga mengembangkan program Bahasa Jawa dan Keterampilan akuntasi.

\section{Pembahasan}

Pertama, mengacu pada data yang telah dideskripsikan pada kegiatan perencanaan, Rencana Pelaksanaan Pembelajaran (RPP) yang disusun oleh guru-guru SMP Negeri 8 Yogyakarta dikembangkan secara rinci dari suatu materi pokok atau tema tertentu yang mengacu pada standar isi dan silabus. RPP dikembangkan dari silabus untuk mengarahkan kegiatan pembelajaran peserta didik dalam upaya mencapai Kompetensi Dasar (KD). Hal-hal yang dikembangkan mencakup: (1) data sekolah, matapelajaran, dan kelas/semester; (2) materi pokok; (3) alokasi waktu; (4) tujuan pembelajaran, KD dan indikator pencapai- 
an kompetensi; (5) materi pembelajaran; metode pembelajaran; (6) media, alat dan sumber belajar; (6) langkah-langkah kegiatan pembelajaran dengan menggunakan pendekatan saintifik; dan (7) penilaian.

Beberapa kegiatan guru tersebut di atas, jika mengacu pada Peraturan Menteri Pendidikan dan Kebudayaan Republik Indonesia Nomor 81A Tahun 2013, tentang implementasi kurikulum, pedoman umum pembelajaran dan mengenai unsur-unsur pengembangannya, maka RPP yang disusun dan dikembangkan oleh guru SMP Negeri 8 Yogyakarta sudah sesuai dengan hakikat RPP pada peraturan tersebut. Kemudian juga, dapat dikatakan pengembangan RPP oleh guru-guru SMP Negeri 8 Yogyakarta telah memenuhi kaidah-kaidah pengembangan RPP yang baik.

Kedua, dalam proses pembelajaran pada Kurikulum 2013 untuk semua jenjang dilaksanakan dengan menggunakan pendekatan ilmiah (saintifik). Tidak terkecuali juga dengan SMP Negeri 8 Yogyakarta. Langkah-langkah pendekatan ilmiah (scientific appoach) dalam proses pembelajaran meliputi menggali informasi melalui pengamatan, bertanya, percobaan, kemudian mengolah data atau informasi, menyajikan data atau informasi, dilanjutkan dengan menganalisis, menalar, kemudian menyimpulkan, dan mencipta. Sebagaimana dijelaskan sebelumnya, untuk mata pelajaran, materi, atau situasi tertentu, di SMP Negeri 8 Yogyakarta pendekatan ilmiah ini tidak selalu tepat diaplikasikan secara prosedural. Misalnya, seperti pada mata pelajaran matematika. Pada kondisi seperti ini, tentu saja proses pembelajaran harus tetap menerapkan nilai-nilai atau sifat-sifat ilmiah dan menghindari nilai-nilai atau sifat-sifat non-ilmiah, namun penerapannya harus disesuaikan dengan materi dan kondisi siswa.

Ketiga, penilaian dalam Kurikulum 2013 mengacu pada Permendikbud Nomor 66 Tahun 2013 tentang Standar Penilaian Pendidikan. Standar penilaian dibuat dengan tujuan untuk: (1) perencanaan penilaian peserta didik sesuai dengan kom- petensi yang akan dicapai dan berdasarkan prinsip-prinsip penilaian, (2) pelaksanaan penilaian peserta didik secara profesional, terbuka, edukatif, efisien, dan sesuai dengan konteks sosial budaya; dan (3) pelaporan hasil penilaian peserta didik secara objektif, akuntabel, dan informatif.

Standar penilaian tersebut, sengaja disusun agar menjadi acuan bagi pendidik, satuan pendidikan, dan pemerintah pada satuan pendidikan untuk jenjang pendidikan dasar dan menengah. Kemudian dalam turunannya Permendikbud Nomor 104 Tahun 2014 dinyatakan bahwa Penilaian hasil belajar oleh pendidik adalah proses pengumpulan informasi/bukti tentang capaian pembelajaran peserta didik dalam kompetensi sikap spiritual dan sikap sosial, kompetensi pengetahuan, dan kompetensi keterampilan yang dilakukan secara terencana dan sistematis, selama dan setelah proses pembelajaran (Mendikbud RI, 2014).

Jika mengacu pada Permendikbud Nomor 66 Tahun 2013 beserta turunannya tersebut, maka dapat dikatakan guru-guru SMP Negeri 8 Yogyakarta telah melaksanakan dan mengimplementasikan penilaian hasil belajar Kurikulum 2013. Hal ini dikarenakan adanya kesusaian antara teknik dan instrumen penilaian yang dilakukan guru dengan format penilaian yang ada pada Kurikulum 2013. Penilaian hasil belajar dalam yang dilakukan guru-guru SMP N 8 Yogyakarta dilaksanakan dalam bentuk penilaian autentik dan penilaian non-autentik, tetapi pendekatan utama dalam penilaian hasil belajar oleh pendidik adalah penilaian komprehensif.

\section{Simpulan dan Saran}

Berdasarkan pemaparan hasil penelitian dan pembahasan di atas, maka dapat disimpulkan sebagai berikut:

Pertama, perencanaan pembelajaran diawali dengan mengkaji Silabus dan merumuskan Indikator. RPP dikembangkan dari silabus untuk mengarahkan kegiatan pembelajaran peserta didik dalam upaya mencapai Kompetensi Dasar (KD). Penyu- 
sunan RPP dan instrumen penilaian dianggap terlalu administratif dan membutuhkan waktu yang banyak, sehingga bisa menghambat penyusunan materi dan strategi pembelajaran.

Kedua, pelaksanaan pembelajaran dilaksanakan dengan menggunakan pendekata ilmiah (saintifik). Langkah-langkah dalam proses pembelajaran meliputi menggali informasi melaui pengamatan, bertanya, percobaan, kemudian mengolah data atau informasi, menyajikan data atau informasi, dilanjutkan dengan menganalisis, menalar, kemudian menyimpulkan, dan mencipta. Dalam prosesnya, pendekatan ini selain membutuhkan waktu yang banyak, juga dianggap kurang cocok diterapkan untuk mata pelajaran matematika secara sintak.

Ketiga, penilaian hasil belajar oleh guru dilakukan dengan menggunakan tes dan nontes dalam bentuk tertulis maupun lisan, pengamatan kinerja, pengukuran sikap, penilaian hasil karya berupa tugas, proyek, penggunaan portofolio, dan penilaian diri. Pada proses pelaksanaannya format penilaian ini dianggap terlalu banyak dalam penggunaan waktu. Sehingga, alokasi waktu dalam melaksanakan pembelajaran menjadi kurang efektif karena harus berbagi dengan waktu penilaian peserta didik.

Keempat, hambatan yang dihadapi dalam melaksanakan Kurikulum 2013 dalam pembelajaran antara lain: (1) Tematik integratif kurang pas dengan pelajaran IPA, sehingga menghambat pelaksanaan pembelajaran. (2) materi banyak, namun alokasi waktu sedikit. Pembelajaran terpadu ternyata tidak membuat pembelajaran di dalam kelas menjadi sederhana, justru bagi guru-guru SMP N 8 lebih rumit. (3) Banyaknya ditemukan kesalahan pada isi atau konten dalam buku Kurikulum 2013. Dari laporan guru, banyak ditemukan kesalahan konsep, ketidak sesuaian isi, dan kurang pasnya isi materi buku pedoman Kurikulum 2013. Kesalahan konsep tersebut menurutnya, akan berdampak sangat fatal dan dapat menyesatkan. (4) Penam- bahan materi terlalu banyak. Selain merasa disibukkan dengan penilaian, pendekatan pembelajaran, Guru-Guru juga mengeluh tentang penambahan materi yang terlalu banyak sehingga kegiatan pembelajaran kurang optimal. (5) Keterlambatan buku pegangan siswa dan buku pegangan guru. Keterlambatan pendistribusian buku dan kesalahan pendistribusian yang sering terjadi membuat guru kebingungan mengimplementasikan Kurikulum 2013. Akhirnya pengembangan materi ajar tidak maksimal. Sedangkan faktor pendukung implementasi Kurikulum 2013 di SMP Negeri 8 Yogyakarta selain didukung oleh SDM yang baik, fasilitas pembelajaran yang baik, juga didukung oleh program-program pengembangan pendidikan yang diantaranya; pengembangan muatan lokal, peningkatan kecakapan hidup, dan peningkatan keunggulan lokal dan global.

Berdasarkan uraian hasil penelitian dan pembahasan yang kemudian disimpulkan, dapat disampaikan saran sebagai berikut. Secara umum implementasi Kurikulum 2013 di sekolah ini sudah berjalan sesuai dengan harapan. Hal ini tanpak dari pelaksanaan pembelajaran yang menggunakan pendekatan saintifik dan penilaian hasil pembelajaran dengan menggunakan penilaian autentik. Namun demikian ada beberapa aspek yang perlu dikembangkan menjadi lebih baik lagi, sebab even the best can be improved. Oleh karena itu peneliti sarankan agar SMP Negeri 8 Yogyakarta tetap berinovasi dan mengembangkan diri denga terus meningkatkan mutu sekolah lebih baik. Di samping itu, ada saran lain yaitu agar supaya keberhasilan sekolah dalam mengimplementasikan Kurikulum 2013 hususnya dalam pelaksanaan pembelajaran disebarluaskan ke sekolah-sekolah yang belum menerapkan K-13. Karena pasalnya sekolah-sekolah tersebut nantinya akan menggunakan K-13.

\section{Daftar Pustaka}

Abidin, Y. (2013). Desain sistem pembelajaran dalam konteks Kurikulum 2013. Bandung: Rafika Aditama. 
Daryanto. (2014). Pendekatan pembelajaran saintifik Kurikulum2013. Yogyakarta: Gava Media.

Fadlillah, M. (2014). Implementasi Kurikulum 2013 dalam pembelajaran SD/MI, SMP/MTS, dan SMA/MA. Yogyakarta: Ar-Ruzz Media.

Hosnan, M. (2014). Pendekatan saintifik dan kontekstua ldalam pembelajaran abad21: kunci sukses implementasi Kurikulum2013. Bogor: Ghalia Indonesia.

Keyes, G. (2010). Teaching the scientific method in the social sciences. The Journal of Effective Teaching, 10(2), 1828. Retrieved from http://www.uncw.edu/jet/articles/ Vol10_2/Volume1002.pdf

Kunandar. (2013). Penilaian autentik: penilaian hasil belajar peserta didik berdasarkan Kurikulum 2013. Jakarta: Rajawali Pers.
Lie, A. (2012). Kooperatif learning (mempraktikkan cooperative Learning di ruang-ruang Kelas). Jakarta: Grasindo.

Mendikbud RI. Peraturan Menteri Pendidikan dan Kebudayaan Nomor 66 Tahun 2013 tentang Standar Penilaian (2013).

Mendikbud RI. Peraturan Menteri Pendidikan dan Kebudayaan Republik Indonesia Nomor 65 Tahun 2013 tentang Standar Proses Pendidikan Dasar dan Menengah (2013).

Mendikbud RI. Peraturan Menteri Pendidikan dan Kebudayaan Nomor 104 Tahun 2014 tentang Standar Penilaian (2014).

Nasution, S. (2003). Asas-asas kuriklum. Jakarta: Bumi Aksara.

Sukmadinata, N. S. (2012). Metode penelitian pendidikan. Bandung: Remaja Rosdakarya. 